\title{
Human Meconium Has a Pulmonary Vascular and Airway Smooth Muscle Relaxant Effect
}

\author{
ROGERIO TESSLER, JINGYI PAN, HUMBERTO HOLMER FIORI, AND JAQUES BELIK

\begin{abstract}
Department of Pediatrics [J.P., J.B.], The Hospital for Sick Children, Toronto, Ontario, Canada M5G 1X8; Department of Pediatrics
\end{abstract} \\ [R.T., H.H.F.], Pontifícia Universidade Católica do Rio Grande do Sul, Porto Alegre, Rio Grande do Sul, Brazil, 90680000
}

\begin{abstract}
Meconium aspiration is believed to cause persistent pulmonary hypertension syndrome of the newborn (PPHN) via vasoconstriction, whereas meconium has a relaxant effect on rat tracheal muscle. We evaluated the meconium effect on lung vascular and airway muscle. Three-days old and adult rat 3rd-4th generation arteries and adjacent bronchi were studied in vitro. Fresh homogenized meconium did not induce arterial or airway muscle contraction. In precontracted arteries, meconium induced muscle relaxation that was greater $(p<0.01)$ in the newborn $(53 \pm 5 \%)$, when compared with adult vessels $(34 \pm 3 \%)$. This relaxant response was partially abrogated $(p<0.01)$ by L-NAME $(28 \pm 4 \%)$ and enhanced by a superoxide scavenger $(55 \pm 4 \%)$. Precontracted bronchial muscle relaxed to meconium in vitro and the magnitude of response was greater in the adult when compared with the newborn $(p<0.01)$. In vitro incubation with meconium $(3 \mathrm{~h})$ reduced agonist-stimulated force and enhanced endothelium-dependent relaxation $(p<0.01)$. Airway meconium instillation followed by mechanical ventilation enhanced thromboxane-induced newborn rat pulmonary arterial muscle contraction in vitro $(p<0.01)$. We conclude that meconium is a pulmonary vasodilator in vitro $\mathrm{M}>$ econium is first noted to be present at $12 \mathrm{wk}$ gestation in humans. It is the by-product of fetal amniotic fluid, lanugo, skin cells, and vernix caseosa swallowing, as well it contains cells derived from the gastrointestinal tract (1). Meconium composition also includes four different biliary acids (cholic, chenodeoxycholic, deoxycholic, and lithocholic) and minerals of which copper, zinc, magnesium, calcium iron, and phosphorus are the most common $(2,3)$. In addition, it contains plasmatic proteins such as $\alpha_{1}$-antitripsin and phospholipase $\mathrm{A}_{2}$ (4,5). (Pediatr Res 64: 24-28, 2008)
\end{abstract}

$\mathrm{T}$ he majority of infants eliminate meconium only after birth. In $15-30 \%$ of pregnancies, the fetal anal sphincter relaxes and meconium is released into the amniotic cavity prenatally (6). The factors responsible for the prenatal release of meconium are unknown. Distress either before, during labor or immediately after birth can result in meconium release and the associated gasping-like breathing activity favors its aspiration leading to a moderate to severe pneumonitis in the immediate postnatal period (6).

Meconium aspiration syndrome (MAS) is often associated and further complicated by pulmonary hypertension in the neonate. The mechanism by which meconium aspiration re-

Received September 5, 2007; accepted February 11, 2008.

Correspondence: Jaques Belik, M.D., Professor of Pediatrics, University of Toronto, Division of Neonatology, Hospital for Sick Children, Room 3886, 555 University Ave, Toronto, Ontario, Canada M5G 1X8; e-mail: jaques.belik@sickkids.ca

Supported by a grant from the Canadian Institutes of Health Research. sults in the so-called persistent pulmonary hypertension syndrome of the newborn (PPHN) is presently unclear. Exposure of airway epithelial cells to meconium induces thromboxane $\mathrm{A}_{2}$ release (7), suggesting that the MAS-associated pulmonary hypertension might be related to synthesis and/or activation of pulmonary vascular constrictor agonists.

Rabbit tracheal tissue exposed to meconium in vitro shows hyperreactivity to histamine, suggesting that meconium has a direct agonist effect on the tracheal smooth muscle (8). In contrast, in vitro meconium exposure of precontracted rat trachea promotes muscle relaxation (9).

Conflicting results have also been reported concerning the human meconium effect of umbilical vessels. Meconium failed to contract umbilical arterial and venous muscle, but significantly reduced the thromboxane $\mathrm{A}_{2}$ analogue-induced force (10). Yet, others found meconium to have a directly vasoconstrictor effect on the human umbilical vein (11). Lastly, in vitro exposure of umbilical arteries and veins to meconium results in histopathologic changes in the endothelial cells (12). Because the umbilical vessels are not innervated and their functional characteristics are distinct from the pulmonary vasculature, these findings are of limited significance to the newborn lung physiology and MAS.

To the best of our knowledge, the effect of meconium on the pulmonary arterial and bronchial smooth muscle has not been previously evaluated. Therefore, the purpose of this study was to evaluate the meconium effect on the newborn and adult rat lung vascular and airway smooth muscle. We used in vitro and in vivo protocols to study the meconium effect. Given the increased pulmonary vascular and airway reactivity in MAS, we hypothesized that meconium has a smooth muscle constrictor effect in the newborn in vitro that is enhanced in pulmonary arteries obtained from a newborn rat model of MAS.

\section{METHODS}

Animals. Young adult (2-4 mo old; $250-300 \mathrm{~g} ; n=16$ ) and 3-d old ( $n=$ 40) Sprague-Dawley rats (Charles River, Ontario, Canada) were studied. The animals were killed with an overdose of pentobarbital sodium $(60 \mathrm{mg} / \mathrm{kg}$ intraperitoneally). All procedures were conducted according to criteria established by the Canadian Council on Animal Care and were approved by The Hospital for Sick Children Research Institute Animal Care Review Committee.

Abbreviations: MAS, meconium aspiration syndrome; PPHN, persistent pulmonary hypertension syndrome of the newborn; U46619, thromboxane $\mathrm{A}_{2}$ analogue 
Human meconium. Fresh first-passed human meconium was obtained from six healthy full-term neonates less than $24 \mathrm{~h}$ of age. The meconium was irradiated, lyophilized, filtered through a large pore mesh to eliminate detritus and frozen at $-20^{\circ} \mathrm{C}$ until the experiment day. All obtained meconium was pooled to minimize individual inter-infant variation. For all myograph studies, meconium was thawed and diluted in Krebs-Henseleit solution to a final bath concentration of $5 \mathrm{mg} / \mathrm{mL}$. In preliminary studies, we determined that this concentration induced significant smooth muscle relaxation in our tissue preparation and is similar to the one used by others to test the meconium effect on the rat tracheal smooth muscle (9). Although the reconstituted meconium preparation used in this study clearly differs from fresh meconium involved in MAS, it allows for the in vitro measurements without the possible confounding effect of bacteria on pulmonary artery tone as shown by others (13).

In vitro studies. Immediately after death, the lungs were harvested and the third (newborn) or fourth (adult) generation left lung intralobar pulmonary artery, or their adjacent bronchus (average diameter 80-100 $\mu \mathrm{m}$ and length $=$ $2 \mathrm{~mm}$ ) were dissected free and mounted in a wire myograph (Danish Myo Technology A/S, Denmark). Tissues were bathed in Krebs-Henseleit buffer $\left(\mathrm{NaCl}, 115 \mathrm{mM} ; \mathrm{NaHCO}_{3}, 25 \mathrm{mM} \mathrm{NaHPO}_{4}, 1.38 \mathrm{mM}\right.$; KCl, $2.51 \mathrm{mM}$; $\mathrm{MgSO}_{4}-7 \mathrm{H}_{2} \mathrm{O}, 2.46 \mathrm{mM} ; \mathrm{CaCl}_{2}, 1.91 \mathrm{mM}$; and dextrose, $5.56 \mathrm{mM}$ ) bubbled with air $6 \% \mathrm{CO}_{2}$ and maintained at $37^{\circ} \mathrm{C}$.

After $1 \mathrm{~h}$ of equilibration, the optimal tissue resting tension was determined by short duration $(1 \mathrm{~min})$ repeated stimulation with $128 \mathrm{mM} \mathrm{KCl}$ until maximum active tension was reached. This procedure does not appear to negatively impact on the muscle response to other subsequent agonist stimulation $(14,15)$. All subsequent force measurements were obtained at optimal resting tension. Muscle relaxation was evaluated by initially precontracting with the $\mathrm{EC}_{75}$ concentrations of either the thromboxane $\mathrm{A}_{2}$-mimetic $\mathrm{U} 46619$ (pulmonary arteries) or the muscarinic receptor stimulant methacholine (bronchial tissue).

Force measurements were recorded online (Myodaq, Danish Myo Technology A/S, Aarhus, Denmark) and normalized to the tissue cross sectional area as follows: (segment length $\times$ segment diameter) $\times 2$ and expressed as $\mathrm{mN} / \mathrm{mm}^{2}$. Once dissected and cut as a ring, the vascular and airway tissue length was measured with a calibrated dissecting microscope eyepiece. The vascular/airway ring diameter was obtained during the muscle length-tension curves where starting from a position where the myograph wires are not touching the inner vessel/airway wall, they were progressively distanced from each other until the optimal muscle length was obtained. The diameter was read in the myograph as the distance between the two wires in a micrometer scale + the sum of the wires' diameter. This is the measurement referred as vessel/airway diameter. Relaxation was reported as a percentage of precontraction active force generation as previously reported by us $(14,15)$.

For the in vitro meconium incubation studies, the freshly dissected pulmonary arteries were incubated with meconium $(5 \mathrm{mg} / \mathrm{mL})$ in KrebsHenseleit solution bubbled with air $6 \% \mathrm{CO}_{2}$ at $37^{\circ} \mathrm{C}$ for 3 hours, before obtaining the muscle force and relaxation measurements.

In vivo studies of meconium airway instillation and ventilation. Newborn animals were mechanically ventilated as previously described (16). Briefly, the animals were sedated with an intraperitoneal injection of a mixture of xylazine and ketamine ( 8 and $80 \mathrm{mg} / \mathrm{kg}$, respectively). Following a small neck incision, a metal cannula (22 gauge, $2.5 \mathrm{~cm}$ in length) was placed in the trachea and firmly secured with a 4.0 silk suture to prevent air leak. The cannula was connected to the mechanical ventilator after which the animal was paralyzed with pancuronium bromide $(0.1 \mathrm{mg} / \mathrm{kg}$ ip). Chest electrodes were placed and the animal's ECG signal was acquired continuously (Hewlett Packard, Palo Alto, CA) to monitor for cardiovascular stability. The animals were kept on a warm circulating water pad to maintain the body temperature constant at $37^{\circ} \mathrm{C}$.

The animals were oxygen-ventilated for $60 \mathrm{~min}$ with a tidal volume of 10 $\mathrm{mL} / \mathrm{kg}$, positive end-expiratory pressure (PEEP) of $2 \mathrm{~cm} \mathrm{H}_{2} \mathrm{O}$ to avoid lung atelectasis, a rate of $60 \mathrm{breaths} / \mathrm{min}$ and $1: 1$ inspiratory/expiratory ratio. A custom made previously described mechanical ventilator was used (16).

Meconium (prepared as described above) was mixed in saline at a concentration of $65 \mathrm{mg} / \mathrm{mL}$. In eight newborn pups, $3 \mathrm{~mL} / \mathrm{kg}$ of meconium suspension was instilled intratracheally with a 25-gauge needle in less than $10 \mathrm{~s}$, immediately after placement of the tracheal cannula. To ensure adequate and uniform airway distribution, half the dose was given with the rat lying on one side and the other half after switching body position to the other side. The control animals received no tracheal instillation $(n=18)$.

Given that the animals were volume-ventilated, no further adjustment of ventilatory settings was necessary. At the end of $60 \mathrm{~min}$ of ventilation, the animals were euthanized with pentobarbital sodium $(60 \mathrm{mg} / \mathrm{kg}$ ip) and the lungs removed for the vessel myograph studies.

These newborn animals are on average 10-15 $\mathrm{g}$ and the only way of obtaining blood gases is by decapitation at the end of the experiment. This procedure results in drainage of blood from the pulmonary circulation making it impossible to recognize the arteries for dissection and isolation for the myograph studies. For this reason, no blood gases and $\mathrm{pH}$ were obtained in the experimental and control animal. In previously published work, we have demonstrated that in newborn rats these ventilator settings result in normal blood $\mathrm{pH}$ at the end of $60 \mathrm{~min}$ ventilation (16). Yet, the experimental animals' gas exchange status may have differed from our own published data because of meconium-induced ventilation-perfusion mismatch.

Drugs. All drugs were obtained from Sigma Chemical Co. Aldrich, Ontario, Canada.

Data analysis. Data were evaluated by either one- or two-way analysis of variance (ANOVA) with multiple comparisons obtained by the TukeyKrammer test when appropriate, or $\mathrm{t}$ test. Statistical significance was accepted at $p<0.05$. All statistical analysis was performed with the Number Cruncher Statistical System (NCSS, Kaysville, UT). Data are presented as mean \pm SEM.

\section{RESULTS}

The newborn and adult rat bronchial and pulmonary arterial smooth muscle force development in response to the thromboxane $\mathrm{A}_{2}$ analogue $\mathrm{U} 46619$ and methacholine, respectively, are illustrated in Figure 1. Significantly higher forces were observed in both adult tissues, when compared with the newborn $(p<0.01)$. In contrast, meconium $(0.1-5 \mathrm{mg} / \mathrm{mL})$ did not contract the newborn and adult pulmonary arterial and bronchial smooth muscle (Fig. 1).

In precontracted bronchial and pulmonary arterial smooth muscle, meconium induced a concentration-dependent relaxation (Fig. 1). In the bronchi, the magnitude of the meconiuminduced relaxation was significantly greater in the adult, as compared with newborn and not altered following NOS inhibition with L-NAME at either age (Fig. 2). Soluble guanylate cyclase inhibition with ODQ $\left(10^{-5} \mathrm{M} ; n=4\right)$ and the addition of tiron $\left(10^{-3} \mathrm{M} ; n=4\right)$, a reactive oxygen species scavenger did not alter the meconium-induced magnitude of bronchial muscle relaxation in the newborn (data not shown).
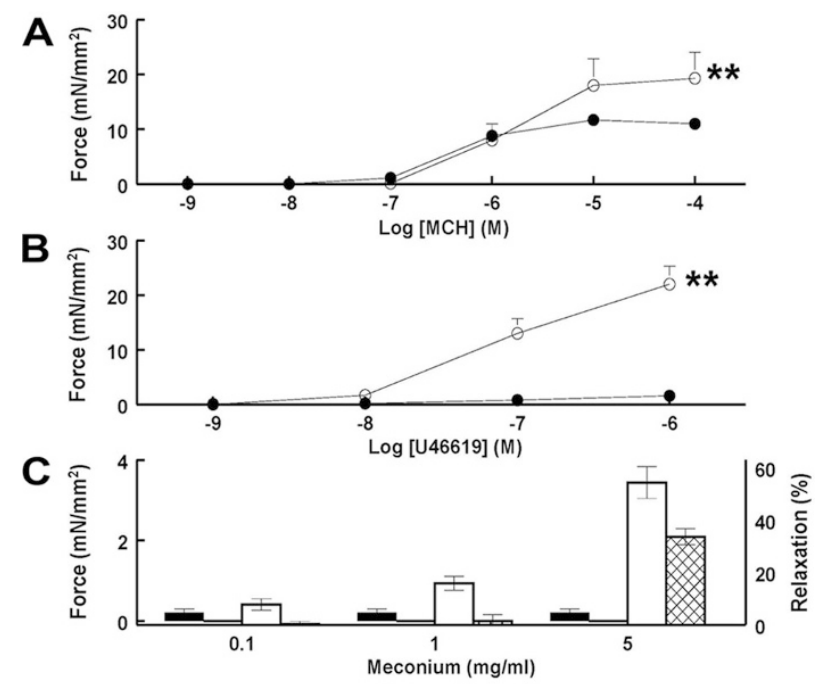

Figure 1. Bronchial $(A)$ and pulmonary $(B)$ arterial smooth muscle doseresponse to methacholine and the thromboxane $\mathrm{A}_{2}$ analogue $\mathrm{U} 46619$ in newborn $(n=8)$ and adult $(n=16)$ rat tissue. Solid circles $=$ Newborn; Open circles $=$ Adult data. $* * p<0.01$ as compared with adult data by two-way ANOVA. $C$, The dose-response of meconium on the adult bronchial $(n=4)$ and pulmonary arterial tissue $(n=4)$. Note that meconium failed to induce muscle contraction, but showed a concentration-dependent relaxation in arteries and bronchial tissue precontracted with U46619 and methacholine respectively. - Force (Bronchi); $\square$ - Force (pulmonary artery); - Relaxation (Bronchi); $\times \times X$ - Relaxation (pulmonary artery). 


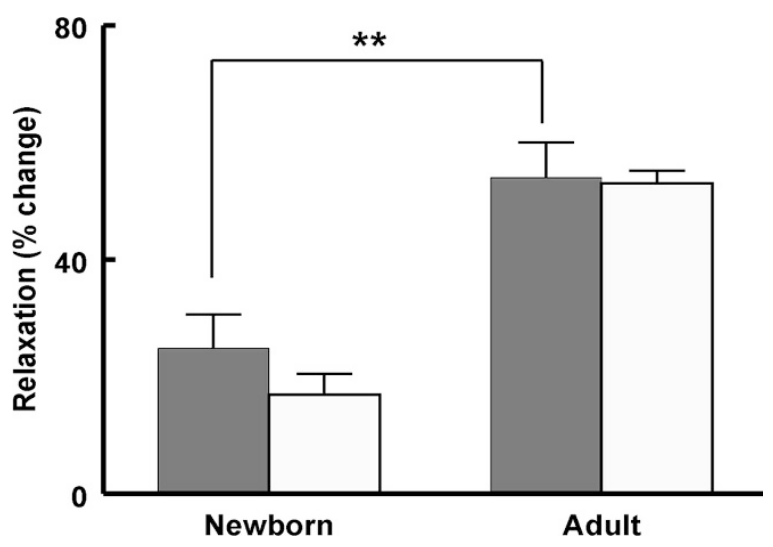

Figure 2. Human meconium $(5 \mathrm{mg} / \mathrm{mL})$ induced newborn $(n=8)$ and adult $(n=16)$ bronchial muscle relaxation in the absence and presence of the nonspecific nitric oxide synthase inhibitor L-NAME $\left(10^{-4} \mathrm{M} ; n=4\right.$ for each age). ${ }^{* *} p<0.01$ by t test. Dark shaded - Control; Light shaded - L-NAME.

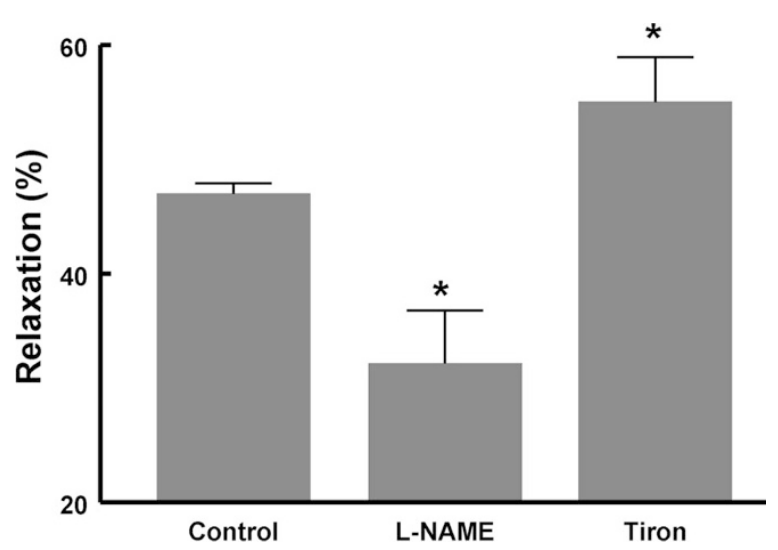

Figure 3. Human meconium $(5 \mathrm{mg} / \mathrm{mL})$ induced newborn pulmonary arterial muscle relaxation in the absence (control; $n=8$ ) and presence of the nonspecific nitric oxide synthase inhibitor L-NAME $\left(10^{-4} \mathrm{M} ; n=8\right)$ and the reactive oxygen species scavenger tiron $\left(10^{-3} \mathrm{M} ; n=4\right)$. $* p<0.05$ vs. control values by one way ANOVA.

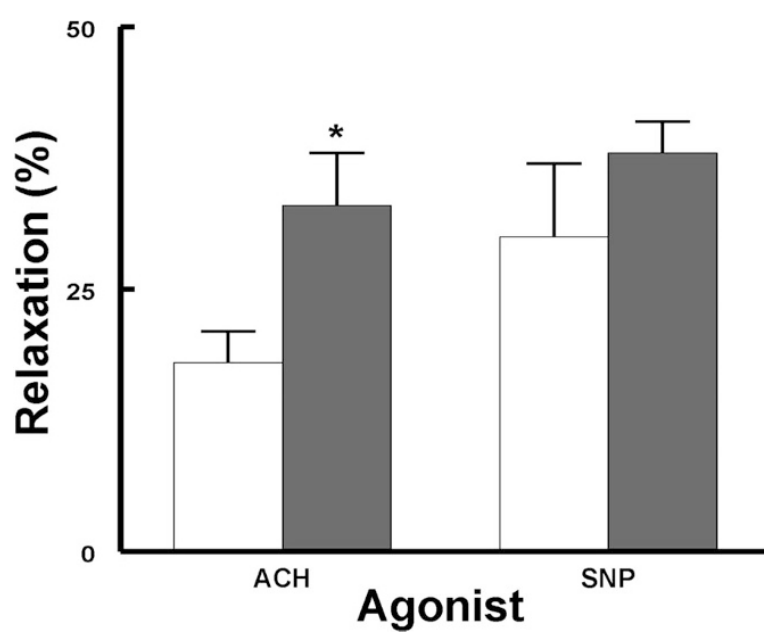

Figure 4. Control and meconium incubated $\left(5 \mathrm{mg} / \mathrm{mL}, 3 \mathrm{~h}\right.$ at $\left.37^{\circ} \mathrm{C}\right)$ newborn pulmonary arteries precontracted with the thromboxane $\mathrm{A}_{2}$ analogue $\mathrm{U} 46619$ $\left(10^{-6} \mathrm{M}\right)$ and relaxed with acetylcholine $\left(\mathrm{ACH} 10^{-4} \mathrm{M}\right.$; endotheliumdependent; control $n=10$; meconium incubated $n=4$ ) and sodium nitroprusside (SNP $10^{-4} \mathrm{M}$; endothelium-independent; control $n=7$; meconium incubated $n=4)$. $* p<0.05 v s$. control values by t test. Light shaded Control; Dark shaded - Meconium incubated.
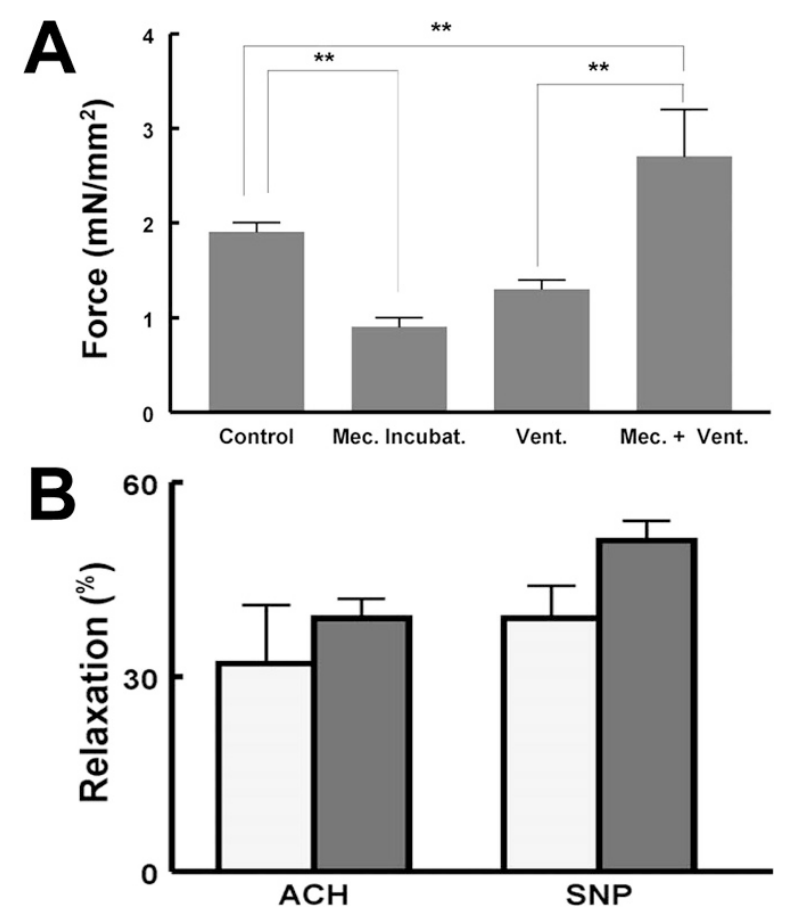

Figure 5. A, Newborn pulmonary arterial muscle force induced by thromboxane $\mathrm{A}_{2}$ analogue $\mathrm{U} 46619\left(10^{-6} \mathrm{M}\right)$ in vessels derived from control $(n=16)$, in vitro meconium incubation $(n=6)$, as well as following $1 \mathrm{~h}$ mechanical ventilation without (Control $n=18$ ) or with meconium instillation (Mec. + Vent. $n=4)$. B, Pulmonary arteries from mechanically ventilated newborn pups without and with lung instillation of meconium. Vessels were precontracted with $\mathrm{U} 46619\left(10^{-6} \mathrm{M}\right)$ and relaxed with either acetylcholine $\left(\mathrm{ACH} 10^{-4} \mathrm{M}\right.$; control $n=5$; Mec. + Vent. $n=4)$, or sodium nitroprusside (SNP $10^{-4} \mathrm{M}$; control $n=$ 18 and Mec. + Vent. $n=4)$. ** $p<0.01$ by t test. Light shaded - Control; Dark shaded - Meconium + ventilation.

The magnitude of meconium-induced relaxation of adult and newborn U46619 precontracted pulmonary arteries was age-dependent, but significantly greater $(p<0.01)$ in the newborn $(47 \pm 1 \% ; n=8)$ when compared with the same generation intrapulmonary arteries of the adult rat $(32 \pm 3 \%$; $n=12)$. L-NAME partially inhibited and tiron enhanced the meconium-induced relaxation of newborn pulmonary arterial muscle (Fig. 3).

We further evaluated the effect of in vitro meconium incubation on the endothelium-dependent and -independent the newborn pulmonary arterial muscle relaxation. In vitro, meconium incubation for 3 hours resulted in enhanced acetylcholineinduced (endothelium-dependent) relaxation $(p<0.05)$, whereas it did not alter the sodium nitroprusside (endotheliumindependent) response (Fig. 4). Meconium incubation also significantly decreased $(p<0.01)$ the newborn pulmonary arterial muscle force following U46619 stimulation $\left(10^{-6} \mathrm{M}\right.$, Fig. 5 Panel A).

To evaluate the in vivo effect of meconium on the pulmonary arterial muscle contraction and relaxation potential, we instilled it in the newborn rat trachea and mechanically ventilated the animals for 1 hour. As compared with vessels from newborn control mechanically ventilated animals, the airway meconium-instilled pulmonary arteries exhibited a significant increase $(p<0.01)$ in U46619-induced force generation (Fig. 5 , Panel A). No significant changes in the pulmonary arterial 
endothelium-dependent and -independent muscle relaxation were noted in the meconium-treated animals (Fig. 5, Panel B).

\section{DISCUSSION}

The meconium aspiration syndrome of the newborn is a clinical condition associated with significant morbidity and need for mechanical ventilatory support (6). When associated with the PPHN syndrome, meconium aspiration may lead to severe hypoxemia, need for extracorporeal membrane oxygenation and poor neurodevelopmental outcome (17).

The pathogenesis of meconium aspiration-induced PPHN syndrome is unclear, but thought to be secondary to the direct pulmonary vasoconstrictor effect of meconium in the lung based on the piglet model of MAS (18). In addition, in the ex vivo perfused adult rat lung instillation of human meconium in the airway induces an increase in pulmonary arterial pressure (19) suggesting that it has a vasoconstrictor effect. In contrast, newborn baboons where human meconium was instilled into their lungs to induce MAS, pulmonary hypertension was not observed up to $24 \mathrm{~h}$ after treatment (20). Although animal species and/or meconium preparation differences may account for the apparent discrepant results, these results raise questions regarding the direct effect of human meconium on the pulmonary vascular tone.

In the present study, we demonstrated that human meconium does not induce contraction and to the contrary has an airway and pulmonary arterial smooth muscle relaxant effect when tested in vitro in rat tissue. Yet, when MAS was simulated by instilling human meconium in the lung of newborn rats an enhanced in vitro pulmonary arterial muscle contractile response to the thromboxane $\mathrm{A}_{2}$ analogue was observed. Together, the study findings suggest that human meconium may induce pulmonary arterial vasoconstriction only when present in the airways/alveoli.

Although this is the first study to evaluate the effect of human meconium on the near resistance pulmonary arteries and adjacent airways, our findings are in keeping with data obtained from other animal and human tissue studies. Human meconium relaxed the rat tracheal muscle (9) and decreased the rabbit tracheal muscle response to histamine (8). This tracheal muscle relaxant effect may be mediated by meconium-induced nitric oxide release from airway epithelium based on experiments involving human cells exposure to meconium in culture (7). It is unlikely, however, that a similar mechanism is responsible for the meconium-induced bronchial muscle relaxation observed in the present study. In the rat bronchi, we were unable to suppress the meconium-induced relaxation with the nonspecific nitric oxide synthase inhibitor L-NAME suggesting that it is not mediated by epithelium-derived nitric oxide.

The effect of meconium on vascular tissue has been previously evaluated in human umbilical arteries and veins. Altshuler et al. reported umbilical vein muscle contraction in response to meconium (11), whereas others showed no direct effect, and a reduced U46619-induced force generation in umbilical arteries and veins in the presence of meconium (10). Umbilical vessels have unique characteristics and these re- ported results may not reflect the newborn pulmonary vasculature response to meconium.

In the present study, we evaluated the effect of human meconium on the newborn and adult rat pulmonary arteries. In thromboxane $\mathrm{A}_{2}$ analogue (U46619) precontracted newborn pulmonary arteries, meconium had a relaxant effect that could be partially abrogated in the presence of a nonspecific nitric oxide synthase inhibitor and enhanced by the superoxide scavenger tiron. Newborn pulmonary arteries in vitro incubation with meconium for 3 hours resulted in a decrease in U46619-induced force. In contrast pulmonary arterial muscle from newborn pups mechanically ventilated for 1-h postmeconium instillation into the lung showed and enhanced in vitro force generation following U46619 stimulation. Taken together, these data suggest that in the rat meconium has no direct pulmonary vasoconstrictor effect. Following airway instillation, meconium likely induces the release of agonist factors by lung parenchyma capable of enhancing the pulmonary arterial constrictor potential.

The nature of these pulmonary vasoconstrictor factors are presently unknown, but meconium has been shown to induce the release of thromboxane (21), complement activation and tumor necrosis factor $\alpha$ (22). Yet, the selectivity for specific agonists, the manner with which it stimulates their release and the time lag between meconium aspiration and pulmonary vasoconstriction in neonates cannot be inferred from the present study.

Last, lung instillation of meconium has been shown in animal models to induce airway epithelial cell and pneumocyte apoptosis via a mechanism that involves the reninangiotensin pathway and angiotensin II production (23-26). Angiotensin type 1 receptors appear to predominate in the adult rat lung and modulate the chronic hypoxia induced pulmonary hypertension (27). Yet, in the rat angiotensin type II receptors predominate during fetal life (28) and the type $I_{A}$ and $I_{B}$ receptors are developmentally regulated (28). Given that the effect of angiotensin II on the newborn rat pulmonary arteries are unknown and possibility absent, the contribution of this agonist to the pulmonary hypertension associated with MAS cannot be ascertained from the present data.

The mechanism by which meconium induces direct relaxation and enhances the acetylcholine endothelium-dependent pulmonary arterial vasodilation in the newborn rat is unclear. The high magnesium content of meconium may play a role, since it inhibits calcium entry and is a known smooth muscle relaxant (29). The fact that scavenging superoxide with tiron enhanced the meconium-induced relaxation suggests that it may induce reactive oxygen species formation thus reducing nitric oxide bioavailability. A role for meconium-induced reactive oxygen species in the pulmonary vascular changes associated with the aspiration syndrome has been suggested by others (30-33).

In summary, we documented that human meconium has a smooth muscle relaxant effect on near resistance airway and pulmonary arterial tissue of the newborn and adult rat challenging the current notion of it being the vasoconstrictor in PPHN syndrome. The mechanism accounting for the clinical 
association between meconium aspiration and PPHN syndromes is unclear. One possible explanation is the meconiuminduced lung release of pulmonary vasoconstrictor humoral factors. Further investigation of the mechanism accounting for the increase in pulmonary arterial pressure following meconium lung aspiration is warranted.

\section{REFERENCES}

1. Righetti C, Peroni DG, Pietrobelli A, Zancanaro C 2003 Proton nuclear magnetic resonance analysis of meconium composition in newborns. J Pediatr Gastroenterol Nutr 36:498-501

2. Rodrigues CM, Marin JJ, Brites D 1999 Bile acid patterns in meconium are influenced by cholestasis of pregnancy and not altered by ursodeoxycholic acid treatment. Gut 45:446-452

3. Haram-Mourabet S, Harper RG, Wapnir RA 1998 Mineral composition of meconium: effect of prematurity. J Am Coll Nutr 17:356-360

4. Holopainen R, Aho H, Laine J, Peuravuori H, Soukka H, Kaapa P 1999 Human meconium has high phospholipase A2 activity and induces cellular injury and apoptosis in piglet lungs. Pediatr Res 46:626-632

5. Zagariya AM, Bhat R, Zhabotynsky E, Chari G, Navale S, Xu Q, Keiderling TA, Vidyasagar D 2005 Characterization of serine/cysteine protease inhibitor alpha1antitripsin from meconium-instilled rabbit lungs. J Cell Biochem 96:137-144

6. Dargaville PA, Copnell B 2006 The epidemiology of meconium aspiration syndrome: incidence, risk factors, therapies, and outcome. Pediatrics 117:1712-1721

7. Khan AM, Lally KP, Elidemir O, Colasurdo GN 2002 Meconium enhances the release of nitric oxide in human airway epithelial cells. Biol Neonate 81:99-104

8. Mokry J, Mokra D, Nosalova G 2006 Direct in vitro effects of meconium on airway reactivity in adult rabbits. Bratisl Lek Listy 107:9-11

9. Collins LC, Roberts AM, Robinson TW, Joshua IG 1996 Direct effects of meconium on rat tracheal smooth muscle tension in vitro. Pediatr Res 40:587-591

10. Montgomery LD, Belfort MA, Saade GR, Moise KJ Jr, Vedernikov YP 1995 Meconium inhibits the contraction of umbilical vessels induced by the thromboxane A2 analog U46619. Am J Obstet Gynecol 173:1075-1078

11. Altshuler G, Hyde S 1989 Meconium-induced vasocontraction: a potential cause of cerebral and other fetal hypoperfusion and of poor pregnancy outcome. J Child Neurol 4:137-142

12. Kafkasli A, Belfort MA, Giannina G, Vedernikov YP, Schaffner DL, Popek EJ 1997 Histopathologic effects of meconium on human umbilical artery and vein: in vitro study. J Matern Fetal Med 6:356-361

13. Villamor E, Perez VF, Tamargo J, Moro M 1996 Effects of group B Streptococcus on the responses to U46619, endothelin-1, and noradrenaline in isolated pulmonary and mesenteric arteries of piglets. Pediatr Res 40:827-833

14. Belik J, Kerc E, Pato MD 2006 Rat pulmonary arterial smooth muscle myosin light chain kinase and phosphatase activities decrease with age. Am J Physiol Lung Cell Mol Physiol 290:L509-L516
15. Belik J, Hehne N, Pan J, Behrends S 2007 Soluble guanylate cyclase-dependent relaxation is reduced in the adult rat bronchial smooth muscle. Am J Physiol Lung Cell Mol Physiol 292:L699-L703

16. Martinez F, Lewis J, Copland I, Engelberts D, Kavanagh BP, Post M, Schurch S, Belik J 2004 Mechanical ventilation effect on surfactant content, function, and lung compliance in the newborn rat. Pediatr Res 56:19-25

17. Khambekar K, Nichani S, Luyt DK, Peek G, Firmin RK, Field DJ, Pandya HC 2006 Developmental outcome in newborn infants treated for acute respiratory failure with extracorporeal membrane oxygenation: present experience. Arch Dis Child Fetal Neonatal Ed 91:F21-F25

18. Srinivasan HB, Vidyasagar D 1999 Meconium aspiration syndrome: current concepts and management. Comp Ther 25:82-89

19. Wisniewski WM, Zagariya AM, Pavuluri N, Srinivasan H, Shankarao S, Vidyasagar D 2005 Effects of meconium aspiration in isolated perfused rat lungs. Pediatr Pulmonol 39:368-373

20. Cornish JD, Dreyer GL, Snyder GE, Kuehl TJ, Gerstmann DR, Null DM Jr, Coalson JJ, deLemos RA 1994 Failure of acute perinatal asphyxia or meconium aspiration to produce persistent pulmonary hypertension in a neonatal baboon model. Am J Obstet Gynecol 171:43-49

21. Khan AM, Lally KP, Larsen GL, Colasurdo GN 2002 Enhanced release of thromboxane $A(2)$ after exposure of human airway epithelial cells to meconium. Pediatr Pulmonol 33:111-116

22. Lally KP, Mehall JR, Xue H, Thompson J 1999 Meconium stimulates a proinflammatory response in peritoneal macrophages: implications for meconium peritonitis. J Pediatr Surg 34:214-217

23. Lukkarinen H, Laine J, Lehtonen J, Zagariya A, Vidyasagar D, Aho H, Kaapa P 2004 Angiotensin II receptor blockade inhibits pneumocyte apoptosis in experimental meconium aspiration. Pediatr Res 55:326-333

24. Vidyasagar D, Lukkarinen H, Kaapa P, Zagariya A 2005 Inflammatory response and apoptosis in newborn lungs after meconium aspiration. Biotechnol Prog 21:192-197

25. Zagariya A, Bhat R, Chari G, Uhal B, Navale S, Vidyasagar D 2005 Apoptosis of airway epithelial cells in response to meconium. Life Sci 76:1849-1858

26. Zagariya A, Bhat R, Navale S, Chari G, Vidyasagar D 2006 Inhibition of meconiuminduced cytokine expression and cell apoptosis by pretreatment with captopril. Pediatrics 117:1722-1727

27. Zhao L, al-Tubuly R, Sebkhi A, Owji AA, Nunez DJ, Wilkins MR 1996 Angiotensin II receptor expression and inhibition in the chronically hypoxic rat lung. Br J Pharmacol 119:1217-1222

28. Grady EF, Sechi LA, Griffin CA, Schambelan M, Kalinyak JE 1991 Expression of AT2 receptors in the developing rat fetus. J Clin Invest 88:921-933

29. Gourgoulianis KI, Chatziparasidis G, Chatziefthimiou A, Molyvdas PA $2001 \mathrm{Mag}$ nesium as a relaxing factor of airway smooth muscles. J Aerosol Med 14:301-307

30. Soukka HR, Ahotupa M, Ruutu M, Kaapa PO 2002 Meconium stimulates neutrophil oxidative burst. Am J Perinatol 19:279-284

31. Hwang SJ, Lee KH, Hwang JH, Choi CW, Shim JW, Chang YS, Park WS 2004 Factors affecting the response to inhaled nitric oxide therapy in persistent pulmonary hypertension of the newborn infants. Yonsei Med J 45:49-55

32. Aaltonen M, Soukka H, Halkola L, Jalonen J, Holopainen IE, Kaapa PO 2005 Meconium aspiration induces oxidative injury in the hippocampus of newborn piglets. Early Hum Dev 81:439-447

33. Craig S, Lopez A, Hoskin D, Markham F 2005 Meconium inhibits phagocytosis and stimulates respiratory burst in alveolar macrophages. Pediatr Res 57:813-818 